\title{
Web 2.0 Technologies and Applications in the Best Practice Networks and Communities
}

\author{
Valentina DAGIENĖ, Eugenijus KURILOVAS \\ Institute of Mathematics and Informatics \\ Akademijos 4, LT-08663 Vilnius, Lithuania \\ e-mail:dagiene@ktl.mii.lt; eugenijus.kurilovas@itc.smm.lt
}

Received: January 2010

\begin{abstract}
The paper is aimed to analyse the external expert evaluation results of eContentplus programme's iCOPER (Interoperable Content for Performance in a Competency-driven Society) project's deliverables, especially quality control and Web 2.0 technologies report. It is a suitability report for better practice concerning the use of Web 2.0 technologies and associated quality control mechanisms within the iCOPER best practice network. It aims to outline the key topics and associated standards and specifications found in this community. These illustrate a set of best practice issues for developing educational resources open for remixing and repurposing, tailored to a European dimension. Information relating to both the evidence and experience of using standards and specifications for the delivery of Web 2.0 tools in the community has also been captured. This includes an indication of the most popular technical platforms for content development, sharing and reuse with respect to the new media as well as an indication of quality control methods for them if used. The paper is also aimed to analyse the first results of Lifelong Learning Programme's (LLP) te@ch.us project. The project plans to set up a web community for teachers interested in integrating Web 2.0 in classes at school.
\end{abstract}

Keywords: Web 2.0 technologies, quality control, content sharing, best practice community, interoperability standards.

\section{Introduction: Web 2.0 Technologies Application in the European Best Practices Networks and Communities}

The aim of the paper is two-fold. On the one hand, the paper is aimed to analyse the external expert evaluation results of the iCOPER project's (iCOPER, 2010) deliverables, especially quality control and Web 2.0 technologies report. This is a suitability report for better practice concerning the use of Web 2.0 technologies and associated quality control mechanisms within the iCOPER best practice network. This analysis is aimed at the Universities sector. It aims to outline the key topics and associated standards and specifications found in this Universities sector community. These illustrate a set of best practice issues for developing educational resources open for remixing and repurposing, tailored to a European dimension.

iCOPER is a Best Practice Network co-funded by the eContentplus programme of the European Community. The 30-months-project started in September 2008 and has the mis- 
sion to collect and develop further best practices for the design, the development and the delivery of interoperable content which supports competency-driven Higher Education.

On the other hand, the paper is aimed at the analysis of the first results of LLP te@ch.us (2010) project aimed at the research on the existing Web 2.0 technologies and web-based teachers' communities for schools.

Web 2.0 technologies are referred here as the technologies that support information and knowledge sharing. They are also often called 'social networking' or 'social computing'.

The rest of the paper is organised as follows: Section 2 is aimed at the analysis of the application of Web 2.0 technologies in Higher Education sector in iCOPER project, Section 3 is aimed at the analysis of the application of Web 2.0 technologies in School Education sector in te@ch.us project. Conclusions and recommendations for both sectors are provided in Section 4.

\section{Analysis of Application of Web 2.0 Technologies in the Universities Sector by the iCOPER Best Practice Network}

iCOPER addresses issues such as: (1) exchange of competency models and learning outcomes, (2) collaboration around learning designs, (3) integration of content via federated search and harvesting, (4) reuse of instructional models and content in learning delivery environments, (5) interoperability of item banks for assessment and evaluation.

Results of recent studies about Web 2.0 teaching and learning in Europe show that existing pilot projects at schools are often driven by single, motivated teachers in grassroot approaches and that apart from support by the school basic knowledge, motivation and inspiration of teachers are necessary for realization of Web 2.0-related innovation. Respective web-based information and communication platforms for the school sector are rare and existing web communities for Web 2.0 teachers are often dominated by experienced members and not focusing on novices regarding structure, contents and communication processes. Responding to this needs the te@ch.us project plans to set up a web-based learning community for teachers who are novices in Web 2.0 and to connect them to experts and experienced teachers for exchange of concepts, experiences and learning materials.

The main impact of the project is the provision of more teachers in schools with basic initial knowledge, inspiration and motivation to use innovative Web 2.0 tools and methods in classes. In long-term a significant increase of the number of innovative Web 2.0 initiatives of schools in Europe is aspired. Several new elements make the given paper distinct from all the other earlier works in the area.

\section{1. iCOPER Partners Case Studies}

Many iCOPER partners offered Web 2.0 use case projects. This confirmed that Web 2.0 tools are deployed across all Higher Education levels and in a variety of subject areas (Ušeckienè and Targamadzè, 2005). 
Table 1

Examples of Web 2.0 related projects implemented by iCOPER partners

\begin{tabular}{lc}
\hline Web 2.0 technology used in the projects & Identified examples \\
\hline Blog & 12 \\
Content rating \& tagging & 4 \\
Discussion fora & 2 \\
ePortfolios & 3 \\
Facebook & 10 \\
Flickr/YouTube/Second Life/Skype & 4 \\
Instant messaging/Google/Doodle & 5 \\
iTunes/podcast/video repositories & 9 \\
Open content repositories & 3 \\
Social bookmarking & 4 \\
Specific editing tools \&/or media libraries & 3 \\
Twitter & 4 \\
Web 2.0 game/3D environment & 2 \\
Wiki & 18 \\
\hline
\end{tabular}

The Table 1 outlines a summary of iCOPER partners' survey on usage of Web 2.0 technologies in their projects.

It is obvious that 23 iCOPER partners representing 18 European countries mostly use Wiki, Facebook, and iTunes/podcast/video repositories in their educational projects.

\subsection{Promotion of an Institutional Perspectives}

Whilst there are few instances of Web 2.0 applications being deployed at an institutional level within the iCOPER consortium, where they do exist offers an excellent insight into their use and potential applications for the wider community. The example of The Open University, UK, employing a number of different, and yet linked, Web 2.0 delivery platforms demonstrates how such technology can be used to communicate with potential, existing and former students.

To deploy such a means of communication it is recommended to develop an institutional wide policy that not only describes the appropriate strategy for such communications but also includes information about the institutional support required for the relevant initiatives or projects to develop successfully.

Interoperability in this context is paramount and applies to both the technical aspects of the individual Web 2.0 platforms (where appropriate) but also affects the strategic view of the communication channels themselves. How each channel is used individually, for what means, as well as how University level 'messages' are promoted across the Web 2.0 platforms is also of primary importance. 


\subsection{Development of Communities Outside the Higher Education Institutions}

Some Web 2.0 based communities appear to have developed in conjunction with Higher Education (HE) institutions. Additionally there is evidence to show that a number of external but University-related groups seem to have been established within the iCOPER community. The latter often build up where students set up their own educational groups but without a specific relationship to the official University administration system. Evidence to support this experience has been offered by a number of iCOPER partners.

Identifying who, why, how and when these related communities develop can be extremely helpful to Higher Education institutions on a number of counts or as Alexander (2008) poses the question in another manner: "How can colleges and universities respond to this world, which has erected itself around us in a very few years?"

Firstly, an understanding of why students want to adapt the technology to suit their own educational purposes can sometimes indicate or enlighten faculty to new applications of Web 2.0 platforms. Secondly, why students or alumni require such communication channels to exchange ideas, knowledge or information may equally be as informative as observing how the channels are used and the technology reused outside the University systems by the student and alumni body.

An example of applied best practice has been offered from The Open University, UK (UKOU). It shows that initially groups of students formed their own course related areas in Facebook before the University deployed its own pages. The student groups demonstrated that they could use the channel as a means of sharing and reuse quite effectively without the intervention of the official University administration. Subsequently the University harnessed the technology at an institutional level, offered specific course related areas and equally also extended the available functionality associated with them (e.g., MyOU Story). This not only offered a means to connect registered students but also promoted the opportunity for communications between a number of groups: potential applicants as well as alumni who could exchange information in addition to the opportunity of offering peer support to their contemporaries.

Another recommendation related to this idea can be extending the access or communication facilities to further communities outside the institution focussing on outreach activities. This would offer opportunities to certain groups to participate in selected University studies whilst also experiencing some defined levels of tutor and peer support. Both the OpenLearn (2010) project (UKOU) and OpenER (by OU of the Netherlands) demonstrate this idea in action through their respective open educational resources projects in action.

\subsection{Encouragement of Staff Development in Higher Education Institutions}

There are strong signals from the iCOPER community that one important aspect of adopting and applying successful Web 2.0 applications in the educational arena is to provide support for staff in terms of raising awareness of the technology as well as how to deploy it effectively and efficiently primarily in teaching situations. The former also applies to 
University-wide applications of Web 2.0 platforms that are used to promote dialogue both within and beyond institutions.

It is fair to state that from the iCOPER community the evidence shows a large number of teaching and administrative staff still appear to be less interested or even resistant to the new technologies. There are many reasons given for this experience (lack of awareness, disinterest in computer mediated communication, perceived time related requirements and so on). A recommendation, therefore, would be to promote an institutional investment in developing staff technology related skills that include the use of Web 2.0 tools integrated in teaching practices.

Such staff development courses should include not only examples of best practice deployment but also include the underlying pedagogical reasons to support the adoption of the different educational delivery channels. Illustrations from within institutions as well as from the wider higher education community are mandatory particularly where successful deployment of Web 2.0 tools have been recognised and enthusiastically received by students.

Minocha (2009) also refers to the need for an awareness of: "What is important is that policy decisions about the expected involvement of all staff are taken". She makes a number of recommendations in the report: A Study on the Effective Use of Social Software by Further and Higher Education in the UK to Support Student Learning and Engagement (Minocha, 2009) that are worth repeating here as evidence of key developments in deploying such technologies:

- be learner-centred;

- consider the impact on staff;

- identify your key stakeholders;

- be convinced yourself;

- be prepared to spend time;

- bdo not hesitate to learn from others.

In the context of adopting Web 2.0 technologies in HE within the iCOPER best practice community it is evident that these stakeholders are both staff and students; that the scenario is an ever-changing one and that institutions need to spend time strategically thinking about how they might best deploy such technologies efficiently and effectively in their institutions.

For instance, the UKOU has invested substantially in staff development on this topic. The University even offers a Masters Level course, open to worldwide distance study, based around the effective educational use of technologies such as those discussed here under the Web 2.0 banner. This course is documented in Thorpe et al. (2009) and accompanied by a number of associated public resources.

Finally it is recommended that by offering staff specific Web 2.0 development courses in multiple delivery modes (e.g., face to face, distance, blended and using Web 2.0 tools) may also enhance and widen the opportunities for staff to engage in learning about Web 2.0, as well as other, educational related delivery platforms. 


\subsection{Summary of iCOPER Expert Meeting Results}

One of the main ideas developed during the first iCOPER experts meeting (incl. external experts, the co-author of the paper being one of them) held in Leuven, Belgium, on 31st of May, 2010, was that the Universities have to support Web 2.0 tools use by the students (as a part of the learning infrastructure), but the teachers have to help students on critical reflect especially on the open user-generated content for outcome-oriented competencydriven learning.

iCOPER is aimed at the establishment of all kinds of eLearning standards and specifications for all stages of learning, i.e., (1) learning outcomes, (2) teaching methods and learning design, (3) learning content, (4) learning as the cognitive process (opportunities, activities, infrastructure), and (5) assessment.

It was commonly agreed by iCOPER community that in order to design a study programme it is necessary (1) first to identify the learner's pre-existing knowledge, skills and competencies, and the learning goals in terms of learning outcomes, and (2) then it is necessary to select a coherent sequence of learning activities to reach the learning goal. This sequence also implies the use of learning resources (objects) in a given learning environment. Since the students actively use Web 2.0 tools as the learning environments and share user-generated resources, the iCOPER architecture should fit this trend at the maximum.

The thematic analysis of iCOPER investigation has revealed that there is strong evidence to support the wide ranging use of Web 2.0 technologies in the iCOPER best practice network. Applications vary within and across institutions. Likewise examples of University led developments also diverge with only one institution demonstrating a linked channel of Web 2.0 communications including strategy and implementation.

Similarly evidence to support the use of quality control mechanisms varied across the iCOPER community. Where such mechanisms existed in relation to Web 2.0 deployment, they were fully integrated with existing University administration systems. More often than not, however, as many Web 2.0 applications were delivered by individual members of staff unless the specific course was already included in institutional quality control mechanisms such work did not appear to take place.

\section{Analysis of Web 2.0 Tools in te@ch.us Community}

\subsection{Literature Review Analysis}

The main objective of te@ch.us project is to set up a web community for teachers interested in integrating Web 2.0 in classes at school. As part of the activities, the project consortium (the authors of the paper and their institution being the members of the consortium) is carrying out establishing network between teachers at different schools. In order to do this, a series of interviews with senior teachers in schools have been started.

The aims of the interviews are:

- to find out whether and in what ways Web 2.0 is currently being used in teaching practices in schools; 
- to establish how Web 2.0 might make a contribution to professional development and improved teaching practice;

- to identify some of the issues that need to be addressed;

- to assess potential demand for setting up a web community for teachers interested in integrating Web 2.0 in classes at school;

- collaborative editing tools allow users in different locations to collaboratively edit the same document at the same time.

One easy way to bring the subject of Web 2.0 for teachers' community is to look at the software that is commonly thought of as Web 2.0 software. Individual systems are hosted on a server and accessed across the web via a browser; they may be interchangeably called Web 2.0 systems, Web 2.0 services, or Web 2.0 applications. For those interested in a comprehensive list of Web 2.0 systems with educational applications it is recommended:

- blogs (originally known as weblogs);

- Wikis;

- social bookmarking: service provides users the ability to record (bookmark) web pages, and tag those records with significant words (tags) that describe the pages being recorded;

- media-sharing services: store user-contributed media, and allow users to search for and display content;

- social networking systems: allow people to network together for various purposes;

- syndication and notification technologies: in a world of newly added and updated shared content it is useful to be able to easily keep up to date with new and changed content, particularly if one is interested in multiple sources of information on multiple web sites.

While analysing relevant literature, the te@ch.us consortium agreed with Andersson (2007) who had suggested a number of examples how to use these technologies in education.

The te@ch.us consortium agreed with BECTA (2007) report which had identified twelve key areas in which Web 2.0 tools are currently being used to support teaching practice:

- trading;

- media sharing;

- media manipulation;

- data/web mashups;

- conversational arenas;

- online games and virtual worlds;

- social networking;

- social bookmarking;

- recommender systems;

- collaborative editing;

- Wikis;

- syndication. 
Table 2

Summary of literature review in te@ ch.us project

\begin{tabular}{ll}
\hline Web 2.0 technology & Key applications \\
\hline Wikis & Supports shift from 'right answers' to 'right questions' \\
& Co-production of knowledge \\
& Text interpretation; critical review of texts \\
& Design for learning \\
& Composition practice \\
& Updating; professional development \\
& Events and information distribution \\
RSS & Critical review \\
& Events and information distribution \\
Blogs & Developing essay plans \\
& Following personal development of students \\
& Making learning material accessible, increasing flexibility and personalisation \\
Podcasts & Field work \\
Immersive environments & Simulations \\
& Supporting new pedagogic and scientific methods, particularly in science, \\
& creative and media subjects \\
Social networking & New visual teaching content \\
& Personal knowledge management \\
& Knowledge exchange \\
&
\end{tabular}

In practical terms, the literature review suggests that different kinds of Web 2.0 can be used in different ways to support more effective learning outcomes. The Table 2 summarises the key conclusions from the review.

The report highlights a particular issue in making technical choices: the 'Walled garden' vs 'Open arena'. Institutions must decide whether to populate the established and open arenas of Web 2.0 activity, or whether to build their own versions of these tools, in order to shape or contain that activity. Teachers may prefer the intimacy and security of protected groups, rather than the uncertain openness of the wider internet. For many commentators, any containment of such activity contradicts the whole spirit of Web 2.0 as a learning resource.

\subsection{Good Practices}

The te@ch.us work plan provides for the development of a database (or 'repository') of these illustrations that will be accessible to members of the te@ch.us community via the on-line platform. The database will thus support the project in developing teachers' Web 2.0 competences. In the initial phase of the project, however, the focus was on using the illustrations to help develop a user needs profile and methodology for service delivery and community development. The database can be seen as an 'evolving' repository of good practices that will grow as the project develops and as more teachers are engaged 
in contributing to sharing their own good practices. This means that the sources from which good practices will be selected for the repository include both 'secondary' material (for example those derived from published reports and existing web-sites) and 'primary' material (for example a video clip of a discussion with a teacher; a video clip of teaching practice using Web 2.0).

The kinds of good practices that could be included in the te@ach.us repository could thus encompass:

- an EU or national programme or project that is developing Web 2.0 training for teaching;

- a commercial Web 2.0 training programme for teachers;

- an article or report on Web 2.0 for teacher training or teaching practice;

- a web-site that provides a forum for knowledge-sharing of Web 2.0 practices amongst teachers;

- an interview with an 'expert teacher' on using Web 2.0 in schools;

- a video clip of a discussion with an expert teacher on how they use Web 2.0 for teaching;

- a video clip of teaching methods and techniques used in school teaching.

The first activity involved searching and collating material for initial review and then selection. The items were drawn from three sources:

- firstly, existing and already known source material;

- secondly, searches of bibliographic databases to expand the existing material;

- thirdly, 'commissioned' material - 'new' material that is specifically developed from scratch by a member of the te@ch.us project to develop an illustration of effective practice. This category covers: interviews with expert teachers; video clips of discussions; video clips of teaching practice

The good practice review involved a 'trans-national' and 'national' dimension, as follows:

- a trans-national review of generic material;

- partners carrying out country reviews (i.e., in their 'host' countries).

A range of examples were identified and analysed. All share in common a focus on supporting professionals and other stakeholders engaged in education to access, master and apply Web 2.0 to improve teaching practice and teaching results. The examples vary widely in how they approach this. One set of cases can be seen as 'repositories' of material to support dissemination of content and practice.

One example is the 'LeMill' (2008) developed during implementation of EU 6FP CALIBRATE (2008) project (the co-author of the paper being the leader of the Lithuanian team in CALIBRATE), which follows an open grass roots approach whereby teachers can create learning material that they can use and share with each other. One of CALIBRATE objectives was to "develop an open source learning toolbox (LeMill) to support the collaborative use of learning resources" (Kurilovas, 2006). At the moment 10565 teachers and other learning content creators are members of the platform. LeMill has 9614 reusable learning content resources, 4358 descriptions of teaching and learning methods, and 955 descriptions of teaching and learning tools. 
Another category covers videos of how to use Web 2.0 in practice. The Teachers TV Blogosphere is an example of an introductory video to blogging to encourage teachers to use blogs for learning. Steve O'Hear ${ }^{1}$ explores how blogs are used in a primary school in Hove and explores how it helps pupils in literacy, ICT skills and a range of other subjects. Blogging assembly, blogs in lessons, after-school blogging club and blogs are used in the school's autistic unit.

A third category covers the use of Web 2.0 applications themselves to deliver and share content and practice on using Web 2.0 for teaching. For example, Welker's Wikinomics ${ }^{2}$ is an online environment offering cooperation, communication and information spaces for students such as a blog and a Wiki. Through using a blog, the teacher can provide real-life examples related to lessons learned in the classroom and the students are able to comment. The Wiki enables students to collaboratively develop a subject-related information environment that supplements - and in the future: replace - textbooks. Additionally, discussion forums are used as tools for communication between students.

Overall, three broad sets of objectives for implementing Web 2.0 have been identified:

- to support exchange of learning content, methods and tools;

- to support collaborative learning and co-production of knowledge and content;

- to support professional development and better teaching practice, including increasing motivation of students to learn.

Four kinds of user group were identified:

- teachers in general, covering primary, secondary and tertiary education;

- teachers in specialist subjects (e.g., languages;

- education managers (e.g., policy and management teams;

- intermediaries (e.g., parents).

\subsection{Current Situation of Web 2.0 Use in the School}

The te@ch.us partners' literature analysis shows the ICT policies and decision-making processes governing the use of Web 2.0 in the schools varied. The UK appears to be the most advanced with regard to developing ICTs. In one UK example, the school policy is to ensure that all areas of the curriculum exploit ICT to benefit the learning experience of students. Every teaching room has an interactive whiteboard and all teachers are issued with a laptop to prepare high quality lessons. Every subject area has a computer room. The school is developing Fronter - a managed learning environment which allows students to access resources and lessons 24/7. It also enables students to have web conversations with staff and each other, e.g., an English group have posted their individual analysis of each others introductory paragraph of a piece of descriptive writing. The school is developing web access to parents and carers so that parents can log in and immediately see their child's live school record including attendance, punctuality, and positive and negative behaviour record.

\footnotetext{
${ }^{1}$ http: //www. ohear.net/

${ }^{2}$ http: //welkerswikinomics.wetpaint.com/
} 
Other countries generally prioritise ICT implementation within the school enterprise, but practices vary. In one Lithuanian example, ICT integration is one of the top priorities at school. It is extensively used throughout the curriculum mainly for demonstration purposes, searching for and presenting information and teaching/learning material, pupils' hands-on practice, content sharing, fostering digital literacy and enriching learning process with interactivity and innovation. Teachers are provided with the necessary equipment and material and encouraged to use ICT in their daily work. There are two computer classrooms which are mainly used for computer studies; however, teachers of other subjects can use them in the available time as well. There is also one computer lab for technology lessons and other subjects. Individual teachers' PCs are available in almost every classroom and several PCs are available for pupils in the library and reading hall.

Overall, 8 schools provided ICT access to students in all classrooms. Only in 1 school was there no formal policy for ICT implementation. In four schools, policy governing the use of Web 2.0 was set by a Strategy Group, normally involving Principal, ICT head and in some cases school governors. In four cases, policy was set by the ICT head and in the remainder of cases by the Principal.

The schools use a variety of Web 2.0 tools - mainly for teaching students but also applied to staff training. Every school bar one uses some form of e-learning platform. The other most widely-used Web 2.0 tolls are blogs (10 out of 13 schools); Wikis ( 7 out of 10) and media-sharing, mainly You-Tube (9 out of 10). RSS and podcasts were used in 6 of the schools. Social networking and bookmarking tools were not widely used ( 3 out of 10 schools) and none of the schools were using virtual environments.

\section{Conclusion and Recommendations}

Web 2.0 technologies are widely used by the students both in the Universities and schools. Therefore the educational institutions' teaching strategies and infrastructure should fit this trend at the maximum. Both Universities and schools have to support Web 2.0 tools use by the students, but the teachers have to help students on critical reflect especially on the open user-generated content.

ne of the important findings of iCOPER Higher Education community is that there is a widespread acceptance that it is 'staff development' which is one of the most significant barriers to the more extensive and effective use of these technologies for learning. Where students are generally seen to be keen to use Web 2.0 systems, and are in general already embedded into social support systems, it is in developing University staff to understand the effective potential that requires significant work. A recommendation, therefore, would be to promote an institutional investment in developing staff technology related skills that include the use of Web 2.0 tools integrated in teaching practices.

According to iCOPER partners survey results (see Table 1), Web 2.0 tools are deployed across all Higher Education levels and in a variety of subject areas. iCOPER partners mostly use Wiki, Facebook, and iTunes/podcast/video repositories in their educational projects. 
According to te@ch.us literature review results (see Table 2), schools mostly use Wikis, RSS, blogs, podcasts, immersive environments, multimedia sharing, and social networking that can be used in different ways to support more effective learning outcomes.

On the basis of the te @ ch.us research, the following recommendations cover the overall strategic and operational principles for developing the project's Web 2.0 platform and community: (1) provide a multi-media platform, including a combination of 'modular' on-line courses, supported by a good practice repository; moderated discussion platform; links to other resources and teaching communities; (2) design the user interface to cater for the target user groups identified and to allow them to easily access their own dedicated user spaces; (3) adopt a 'scaffolded' approach to cater for the different skills levels, motivations, needs and scenarios of use associated with the different user groups.

Acknowledgement. The work presented in this paper is partially supported by the European Commission under the LifeLong Learning programme - as part of the te@ch.us (Learning community for Web 2.0 teaching) project (project No. 504333-LLP-1-2009-1DE-COMENIUS-CMP). The authors are solely responsible for the content of this paper. It does not represent the opinion of the European Commission, and the European Commission is not responsible for any use that might be made of data appearing therein.

\section{References}

Alexander, B. (2008). Social networking in higher education in the tower and the cloud: higher education in the age of cloud computing. Educause, Boulder, Colorado.

Anderson, P. (2007). What is Web 2.0? Ideas, technologies and implications for education. JISC TechWatch http: / /www.jisc.ac.uk/media/documents/techwatch/tsw0701b.pdf.

BECTA (2007). Web 2.0 Technologies for Learning at KS3 and KS4: The Current Landscape-Opportunities, Challenges and Tensions. Available at: http: / / research. becta.org.uk.

CALIBRATE (2008). 6FP CALIBRATE - Calibrating eLearning in Schools Project Web Site. Available at: http: / / calibrate.eun.org.

Facer, N., Selwyn, K. (2007). Beyond the Digital Divide: Rethinking Digital Inclusion for the 21st Century. Futurelab.

iCOPER (2010). EU eContenplus Programme's iCOPER Project (Best Practice Network) http: / /www. icoper.org/.

Kerres, M. (2006). Potentiale von Web 2.0 nutzen. In: A. Hohenstein \& K. Wilbers (Eds.), Handbuch ELearning. München, DWD.

Kurilovas, E. (2006). Virtual learning environments: benefits and potentials to support social constructivist pedagogies. In: Proceedings of the 2nd International Conference "Informatics in Secondary Schools: Evolution and Perspectives" (ISSEP). Vilnius, Lithuania, 166-175.

LeMill (2008). Web Community for Finding, Authoring and Sharing Open Educational Resources. Available at: http://lemill.net/

Minocha, S. (2009). A Study of the Effective Use of Social Software to Support Student Learning and Engagement, JISC, University of Bristol. Available at:

http: / / www.jisc.ac.uk/whatwedo/projects/socialsoftware08.aspx.

OpenLearn (2010). Corse Materials of Open University, UK, web site. Available at: http: / / openlearn. open.ac.uk/.

te@ch.us (2010). Helping Teachers Integrate Web 2.0 into the Classroom. EU LifeLong Learning Programme's te@ch.us Project (Learning community for Web 2.0 teaching). Available at: http: / /www. europeanschoolnet.org/web/guest/about/release/-/asset _publisher $/ 0$ Tqh/content $/ 20655$ ? redirect $=\% 2$ Fweb $\% 2$ Fguest $\% 2$ Fabout $\% 2$ Frelease. 
Thorpe, M., Greaney, P., Pettit, J. (2009). A Guide to Using Delicious, Google Reader and Twitter in the Context of an Open University course: H800 Technology-Enhanced Learning: Practices and Debates. Available at: http://www.open.ac.uk/cetlworkspace/cetlcontent/documents/ 4 a27ee9decbae.pdf.

Ušeckienè, L., Targamadzè, V. (2005). Challenges of sustainable development education tohigher education in Lithuania. Journal of Baltic Science Education, 2(8), 68-79.

V. Dagienè is head of department at the Institute of Mathematics and Informatics. She has published over 150 scientific papers, written more than 60 textbooks in the field of informatics for secondary education and teacher training. She has been chair of Lithuanian Olympiads in Informatics for many years, organized Baltic Olympiad in Informatics in 1997, 2002, and 2005, and established the International Contest on Informatics and Computer Fluency "Bebras". She is vice chair of the IFIP (International Federation for Information Processing) TC3 Committee on Education, and member of the International Committee on Olympiads in Informatics (2006-2012).

E. Kurilovas is a doctor of technological sciences (informatics engineering). He is a research scientist in the Institute of Mathematics and Informatics, an associate professor in Vilnius Gediminas Technical University, and the head of International Networks Department of the Centre for IT in Education of the Ministry of Education and Science of Lithuania. The main areas of his scientific interest are: technology-enhanced learning problems analysis; e-learning systems architecture; metadata, interoperability and standards; usability of learning objects, their repositories and virtual learning environments; e-learning systems' components quality evaluation problems; personalisation and optimisation of the learning process.

\title{
Antrosios kartos saityno technologijos ir geriausios praktikos tinkluose ir bendruomenèse taikymai
}

\author{
Valentina DAGIENĖ, Eugenijus KURILOVAS
}

Straipsnyje analizuojamos eContentplus programos iCOPER projekto išorès ekspertinio vertinimo rezultatu ataskaitos, ypač - kokybès kontrolès ir antrosios kartos saityno (Web 2.0) technologijų. Tai yra Web 2.0 technologijų ir atitinkamu kokybės mechanizmu naudojimo iCOPER tinkle geriausios praktikos taikomumo pagrissta apžvalga. Pagrindinis jos tikslas - identifikuoti svarbiausius šiai bendruomenei klausimus, nustatyti standartus ir specifikacijas. Šie standartai ir specifikacijos iliustruoja atvirų modifikavimui švietimo ištekliu plètros geriausią praktiką, atitinkančią Europinę dimensiją. Be to buvo analizuojami sprendimai ir patirtis, susiję su Web 2.0 priemoniu pateikimo bendruomeneje standartais ir specifikacijomis, t.y. buvo identifikuotos populiariausios techninès platformos turiniui pateikti, mainams ir pakartotiniam naudojimui bei atitinkami kokybès kontrolès metodai. Straipsnyje analizuojami ir pirmieji „Mokymosi visą gyvenimą“ programos „te@ch.us“ projekto igyvendinimo rezultai. Projekto metu planuojama sukurti mokytoju interneto bendruomenę, suinteresuotą antrosios kartos saityno technologijų integravimu mokyklose. 
